\title{
Primordial, Sacred, and Secular Architecture: Jan Patočka’s Theory of the Work of Architecture*
}

\author{
Miloš Ševčík \\ University of West Bohemia in Pilsen, Pilsen, Czech Republic
}

\begin{abstract}
The paper deals with Jan Patočka's considerations on architecture. It presents Patočka's concept of space as the union of two sensory fields, the kinaesthetic-tactile and the visual, and it emphasizes that this union is considered as the "primordial architecture". According to Patočka's view, the material architecture is only a consequence of the primordial architecture. The paper also follows Patočka's idea of the "sacral transubstantiation". Patočka argues that, traditionally, the construction of a work of architecture is considered as dependent on favourable conditions, on divine consent with such a construction and the movement of divine powers into constructed work. The origin of architecture is thus religious. The paper considers the relations and differences between the sacred and secular architecture. It highlights Patočka's idea that both sacred and secular architecture open a certain world, even thought, the status of the world of sacred architecture differs considerably from that of the world of secular architecture.
\end{abstract}

Keywords: Jan Patočka, space, architecture, art

\section{Introduction}

In this paper, the author considers the theory of architecture of the Czech phenomenological philosopher Jan Patočka. ${ }^{1}$ The author proposes that its important features can be properly presented only after Patočka's conception of the construction of space is first taken into account. The author therefore addresses Patočka's conception of the relationship between "primordial architecture", constructed of sensory fields, and "material architecture" of the real building. The author also presents Patočka's idea of sacred transubstantiation, that is, the idea of the incorporation of divine powers into material architecture. With the help of this idea, the author aims to demonstrate both the similarities and the contrasts between Patočka's theory of architecture and Heidegger's notion of the building as a preservation of the oneness of the earth, the sky, mortals, and the divine. The author

\footnotetext{
* Acknowledgments: This study was supported within the project of Education for Competitiveness Operational Programme (OPVK), Research Center for the Theory and History of Science (Výzkumné centrum pro teorii a dějiny vědy), registration No. CZ.1.07/2.3.00/20.0138, co-financed by the European Social Fund and the state budget of the Czech Republic.

Miloš Ševčík, Ph.D., Department of Philosophy, Faculty of Philosophy and Arts, University of West Bohemia in Pilsen.

1 Jan Patočka (1907-1977) is generally considered to be the most important Czech philosopher of the 20th century. He studied in Prague, Paris, Berlin, and Freiburg; he was a pupil of Edmund Husserl and Martin Heidegger. Patočka dealt mainly with the problem of the "natural world", especially its structure, consisting in three fundamental movements of existence. Working on the problem of the natural world, he developed Husserl's, Heidegger's, and Fink's concepts. The most significant of Patočka's works are Natural World as a Philosophical Problem (Přirozený svět jako filozofický problem, 1936), An Introduction to the Husserl's Phenomenology (Úvod do Husserlovy fenomenologie, 1965), and Heretical Essays in the Philosophy of History (Kacírské eseje o filosofii dějin, 1973-1976).
} 
emphasizes that Patočka supposes that only sacred architecture can be explained on the basis of sacred transubstantiation and that secular architecture must be explained on the basis of another principle. In this context, the author follows Patočka's concept of the historical development of culture and endeavours to demonstrate that both sacred and secular art offer a certain truth, even though the status of the truth of sacred art and of secular art differ radically from each other. Sacred art is the depiction of divinity and modern secular art is the expression of human freedom. The author concludes that this expression is also the principle of modern secular architecture.

\section{Primordial and Material Architecture}

In the essay "Space and Its Problems" (Prostor a jeho problematika, 1991), Patočka offered a historical survey of the conceptions of space, and also criticized modern conceptions of space. He argues that the modern conception of geometrical space is artificial. Space is originally not objective, geometrical, and ordered, but subjective, personal, and ordering (Patočka, 1991, pp. 7-16). Also, in the essay “Thoughts on Read's Book about Sculpture" (Úvahy nad Readovou knihou o sochařství, 2004c), he argued that modern science and objectively, scientifically oriented, modern philosophy neglect the "dramatic character" of space; modern science and scientifically oriented philosophy concentrate only on the material and relational aspect of space, on space as a material and relational fact. The dramatic character of space is only revealed, Patočka argues, if space is considered as an ontological fact, as a "structural factor of being" (Patočka, 2004c, p. 450).

In "Space and Its Problems", Patočka states that the subject's presence in space is established by the fact of the "original inside" (Patočka, 1991, p. 16). The relation originating a space is not a relation in space; the original inside is not inside an objective space. The original inside is not the objective relation, that is, a certain relation in an objective space; rather, it is the subject's relation to "beings as a whole". The original inside in the same way incorporates and detaches the subject from beings as a whole. It is "equally in and out", because "incorporating the subject into this whole is impossible without detaching the subject from it". Similarly, in "Thoughts on Read's Book about Sculpture", Patočka proposes that space — as a structural factor of being — places us in beings as a whole of by distancing us from beings of this whole at once. Only on the basis of this "placing distancing" (umistujicí distancováni) can individual things appear, that is, become apparent (Patočka, 2004c, p. 450). It is obvious that Patočka develops Martin Heidegger's concept of the relation of human existence to "Being" in such considerations. ${ }^{2}$ In his famous essay "What is Metaphysics?" (1978b), Heidegger said that human existence is originally related to "beings as a whole" by the "receding" of beings from this existence (Heidegger, 1978b, p. 103). Such a receding of beings is, however, identical with the meeting of Being.

In "Space and Its Problems", Patočka argues that the original inside is the "relation to the universe" and that this relation is the manner of existence of the subject (Patočka, 1991, p. 16). But this original inside is ambiguous. It presents the relation to the whole, which is distant, hidden, and unknown, but also the relation to a differently conceived whole, which is present as the context or overall scheme of the relations of things (Patočka, 1991, pp. $16,20)$. On the one hand, the universe is infinite and the boundaries of this universe remain in the dark. On the

\footnotetext{
2 Patočka is, however, highly critical of Heidegger's omission of the bodily character of human existence. He considers Heidegger's view of human existence to be overly "formal". Patočka argues that only with a view of the bodily character of human existence is it possible to present the correct description of space (Patočka, 1992, p. 217). Patočka repeatedly expresses such a conviction.
} 
other hand, the universe is to be understood as an illuminated horizon of beings. The universe therefore has both a dark and a bright side; it is both unmanageable and enables things to be managed. The original inside — as an overall schema of relations - thus enables contact with concrete things. It contains references to the possibilities of concrete contact with things. The subject led by these references comes into contact with its surroundings. At the moment of contact, one concrete object steps out of these surroundings, and at the next moment another object steps out. The vicinity of the subject is thus changing, continually "undulating" (Patočka, 1991, p. 17). The subject stands in the centre of this "undulating" vicinity; it is surrounded by changing objects. The original inside is thus specially structured. The centre of it is subjective; changing objects or other subjects and the infinite periphery surrounds the subject. Patočka stresses that the subject always strives to establish communion with objects and other subjects and even with the infinite periphery. This harmonization or solidarity with vicinity and periphery is the essence of human "living", the essence of human "residing" (Patočka, 1991, pp. 19-20).

The subjective and personal space presents the union of two sensory fields, the kinaesthetic-tactile and the visual (Patočka, 1991, pp. 22-24). The kinaesthetic-tactile field is the dimension of active interaction with objects; it is the field of the unending search for objects, unending "groping". This field is always open; it is without limits. The subject is able endlessly to proceed forward to the individual objects or subjects in this field. By contrast, the visual field provides a feeling of closeness to the horizon. This field is always closed; it offers "the limit as a whole". This whole is not the object or the complex of objects; it is infinity itself. The horizon is "inexhaustible and hidden infinity". The two sensory fields are therefore both related and opposite. In the kinaesthetic-tactile field the subject goes into the distance; in the visual field, the distance moves towards the subject, "falling down" on the subject. Patočka says that the "joining" of these two fields is "the primordial architecture", the primordial building. Material architecture is only a consequence of this fundamental joining of the fact of the joining of "the tactile vertical and the visual horizontal". Already in its active relation to individual objects or subjects surrounded by the visual horizon, the subject strives for a harmonic relation to the world. The subject creates the secure "home", which incorporates all that is "close and friendly" but also all that is "distant and strange". Such a home is, however, secure only in contrast to the thread of the cosmic horizon. It is possible to conclude that the construction of material architecture, that is, the material realization of a secure and friendly home, ensues from the construction of sensory fields. The tactile field of action and the visual field of closeness find their counterparts in a material building. The material home presents the creation of the inner space covered against the outer space; material architecture is the realization of the secure and friendly inside.

\section{Sacred Transubstantiation}

Patočka points out that the closeness of the human subject to the visual horizon radically differs from every other closeness, because the closeness to the horizon is the "pure inside", that is, it is closeness without the outside. Patočka says that this closeness to the visual horizon is the source of the "architectural feeling". This architectural feeling is never absent from the life of a human being. Originally, however, this feeling was unnoticed; it presented the "invisible film of everyday experience and acting". Only later, did it become the subject of "active forming and developing" (Patočka, 2004c, p. 452). Patočka suggests that this feeling is the source of the "desire for a private room" (Patočka, 1991, pp. 35-36). This desire was satisfied by human beings initially settling in caves. The cave presented not only the inside covered from the unsecure outside, but it also 
brought the possibility of organizing private and social life. But the desire for the secure and friendly inside was satisfied only in the emergence of the house. Strictly speaking, the emergence of the house enabled privacy and it "rooted" life.

Patočka argues that the successful construction of the house was not traditionally seen as an altogether autonomous fact, as a fact totally independent of favourable conditions. Such a work is successful only if divinity enables it, agrees with the "transformation and formation" of materials and "the humble and the rich gifts of the soil", only if the "superhuman being" consents to the use of "soil, stone, and wood" and to the creation of a special "pattern and rhythm" (Patočka, 1991, p. 37). The settling of a house, village, or town is the result of a common decision taken by the closest and the most distant, the human, and the cosmic. Patočka proposes that the origin of architecture is cultic and religious. The material building presents the concentration of divine powers coming from the visual horizon into the centre of the visible world. Patočka depicts this process of concentration of divine powers as "sacred transubstantiation" (Patočka, 1991, p. 24). Sacred transubstantiation "obliges" the "building tendency", it offers an objective — or rather "super-objective"—explanation of this tendency, Patočka says. Sacred transubstantiation enables this tendency to "become conscious" and to become conscious as "building of the universe". Sacred transubstantiation also presents the human role in this building as passive, imitative, and unimportant. What exactly is this sacred transubstantiation? It is the movement of the world horizon to the centre of the world. Divine powers coming from the periphery of the world become the centre of the world from their own decision and initiative, the absolute reveals itself. Patočka suggests that the absolute thus enables orientation in the world; the place of epiphany becomes the centre of this orientation. Epiphany categorizes the entities of the world; this fundamental categorization differentiates in particular the sacred from the profane, that is, differentiates "true, really existing being" from "weakened and dying" being. From this moment, the tendency of building obtains the "overall plan and concept"; it stands on an overall scheme of relations (Patočka, 1991, pp. 24-25). The ways that the divine is in contact with the profane and consequently also the results of the sacred transubstantiation in architecture of course differ greatly.

In some respects, Patočka's concept of sacred transubstantiation brings to mind Heidegger's idea of the relation of the "fourfold" to buildings. In his essay "Building Dwelling Thinking" (1971), Heidegger stated that "building is really dwelling" and that dwelling secures the fourfold - that is, the "simple oneness" of "the earth, the sky, mortals and divinities"-in things (Heidegger, 1971, pp. 149-150). In general, there are two modes of dwelling: the building that cultivates growing things and the building that erects buildings. The nature of buildings is thus preserving and guarding the fourfold. Genuine buildings "give form to dwelling"; they present a particular response to the "summons of the fourfold". All the planning and all the constructing of buildings remains "based on this responding" (Heidegger, 1971, p. 159). Heidegger supposes that dwelling is the universal nature of buildings. Buildings always preserve the fourfold, whether this is evident in them or whether obstructed (Heidegger, 1971, p. 153). Even though Patočka's idea of the relation of the building to the divine powers coming from the visual horizon is very similar to Heideger's idea of keeping the fourfold in the edifices, the important differences between the two authors' concepts are obvious as well. In contrast to Heidegger, Patočka recognizes that it is impossible to explain the nature of modern architecture by the idea of sacred transubstantiation, that is, by the idea of the reunion of the absolute powers and human work in the movement of the world horizon into the centre of the world. Another explanation must be found for the character of modern secular architecture. 


\section{The Dialectics of the Outside and the Inside}

In "Thoughts on Read's Book on Sculpture", Patočka follows Herbert Read's concept of the relation of sculpture and architecture (Patočka, 2004c, pp. 452-453; Read, 1961, pp. 3-24). Patočka accepts Read's idea that both architecture and sculpture grow from a common root. This root is the monument, originally of compact and nonorganic appearance. In the monument emerged a case for a "tactile image" of god. The monument thus became hollow; it started to enclose space. From that time, architecture develops, the origin of architecture is thus sculptural, concludes Read. Both architecture and sculpture create real objects in a real space. The difference between them lies in the fact that architecture encloses space, whereas sculpture occupies it. Architectural space, empty space could, Read points out, be thematic, as it is in ancient Roman architecture, or non-thematic, as it is in ancient Greek architecture. In respect to this architectural inside, the problem of shaping of a corresponding outside emerged. There were two possibilities of this shaping, the first - the total sculptural decoration of the Indian temple, the other-the Greek solution, entailing the concentration of sculptures on tympanons and metopes and the geometrical organization of the remainder of the temple, including the rows of columns. Read adds that in ancient Roman and early Christian architecture, the empty interior of the church became the most important artistic element to be outlined. The rows of columns occupied the inside and started to present the foreground on the background of the vault. In Gothic architecture, Patočka adds, the elevation of the vault, the enlargement of the inside, led to the problem of how to shape the outside again. In this respect, the Gothic solution was analogous to the Indian; Renaissance architecture adopted the Greek solution with certain modifications (Patočka, 2004c, p. 453).

Patočka says that it is possible to find the "true crux" in Read's dialectics, but he also states that such a dialectics of the inside and outside should be considered on the basis of the properly understood difference between sensory fields, the visual and the kinaesthetic-tactile (Patočka, 2004c, pp. 441, 451). In other words, Patočka supposes that the polarity and the solidarity of the kinaesthetic-tactile and the visual presents the origin of the dialectics of the inside and the outside in the development of sculpture and architecture. On the one hand, the monolith makes sense only if it is related to the optical periphery, only if the "magical omnipotent power incorporates into it". The monolith as the divine axis of the world order is thus closely related to the visual horizon, to the optic periphery, which "contains and encircles" all human beings and things, which is sensorily present as something beyond presence. This periphery "encloses everything and gets lost in uncertainty". The monolith as the prototype of a temple thus makes sense only in relation to the periphery incorporating divine powers into it. On the other hand, the emergence of inner architectural space itself also has a very important relation to the visual horizon. The inner space of a high vaulted church was created by limiting the encirclement of the visual "sphere" by transferring it into the inside of a former monolith (Patočka, 2004c, p. 452). The process of development of an architectural outside and inside is, in fact, the process of "harmonic crystallization" growing from the "absent presence" of a visual horizon (Patočka, 2004c, p. 453).

Patočka (2004c) said that the optic closeness of the space presents the "sensory realization" of the ontological fact of the original inside (p. 453). Similarly, he (1991) also mentioned that the visual horizon "exemplifies" the fact that human existence is "always inside" (p. 24). It is thus reasonable to conclude that because the "absent presence" of a visual horizon is the sensuous manifestation of the original inside the 
dialectics of the architectural inside and outside must be "anchored" in the fact of the "inside". The original inside is the basis of the dialectics of the outside and the inside described by Read, Patočka (2004, pp. 450-451) said. He remarks that Read did not mention this original inside, because he considered only aspects of artworks. Patočka concludes that every architectural work - and also every sculptural, visual, or even literary and musical artwork - reacts to the fact of the "inside"; it presents an answer to such a fact. It must thus "create the space" in a certain manner. The visual artwork of course creates the illusion of space, whereas the literary or musical artwork evokes the representation of space. Only the sculpture or building creates "real objects in real space". But the sculpture "occupies" space, whereas architecture "encloses" it. Patočka says that the sculptural work remains "compact", whereas the architectural work creates "empty space", regardless of whether this emptiness is conscious or unconscious.

One notes a striking similarity between Patočka's and Heidegger's thoughts on the relationship between art and space. In this respect, both authors also consider the role of architecture similarly. In the essay "Art and Space" (1973), Heidegger considered the relationship between the work of art and space. He says that in the work of art "genuine space" is uncovered. The work of art is a "clearing-away" and a freeing from "wilderness" (Heidegger, 1973, p. 5). This clearing-away of genuine space is the release of secular and sacred spaces; it is the release of the locations of "possible dwellings for man, the regions of the possible tarrying of things surrounding and concerning man" (Heidegger, 1973, p. 8). Such a release is, however, the "unconcealment of Being" (Heidegger, 1973, p. 8). In "Being Dwelling Thinking", Heidegger argues that building as dwelling produces "locations" and that these locations provide "spaces". He says that "building, by virtue of constructing locations, is a founding and joining of spaces". The locations are, however, produced as buildings and other works of architecture and engineering. Building thus receives "from the fourfold the standard for all the traversing and measuring of the spaces that are provided for by the locations" that were founded as buildings (Heidegger, 1971, p. 158). ${ }^{3}$ But Heidegger also argues here that dwelling is the "character of Being". In "Thoughts on Read's Book on Sculpture", Patočka argues very similarly that art relates space essentially; it attempts to give human existence the essential foundations, the "relation to being". But, Patočka says, to relate being means to "dwell" in the world and to "build". And to build means to live in space. Art is thus necessarily in relation to space. In the proper sense, it relates to the dramatic aspect of space; it grasps space as a structural factor of being. The work of art thus builds in a "most fundamental sense of the world", because it shows us the "dimensions" of space; it enables us to live in a space of a certain character, to deal with and to meet beings of a certain character. Only the work of art enables the encounter of the "absent and present", of the "unreal and real"; the divine, for example, is "among us" in an ancient temple and the transcendent is "here" in a Gothic church (Patočka, 2004c, p. 451).

\section{Secular Architecture as the Heir of Sacred Architecture}

In "Space and Its Problems", Patočka emphasizes the historical importance of the sacred understanding of architecture. The sacred orientation of architecture is demonstrated by the nature of private and public buildings from archaic, ancient, and medieval times. Houses, churches, places of sacrifice, places of celebration, and also

\footnotetext{
${ }^{3}$ Heidegger's view on the status of the mathematical or the physical concept of space is very similar to Patočka's as well. Heidegger believes that such a concept is artificial. He argues that dwelling is much closer to the "origin of the nature" of space then any geometry or any mathematics (Heidegger, 1971, p. 158), "Physical-technical" space cannot be considered genuine space (Heidegger, 1973, p. 5).
} 
entire villages and cities manifest the "sacred understanding of space". In these periods, the "house is the image of the universe" and the "church is the house of God" (Patočka, 1991, p. 26). Patočka (1991) argued that modern secular architecture only develops "the heritage" of sacred architecture (p. 26). But what exactly is inherited? It is clear that the heritage of sacred architecture does not consist only in concrete modes of the construction of buildings and the planning of villages, towns, and cities. And it is obvious that Patočka believes that the sacred building of space contains something that the secular building of space also contains. The sacred orientation of architecture is the manifestation of a certain understanding of the beings as a whole. If secular architecture is considered the heir to sacred architecture, one must conclude that modern secular architecture is also connected to a certain understanding of beings as a whole. The "building" of the "whole world" (Patočka, 1991, p. 26) is thus founded on both sacred and secular architecture. But, the author would note, the concept of heritage includes both continuation and change.

The author has already mentioned that Patočka considers architectural artworks to be real objects creating an empty space and presenting the dimension of space. In the essay "Hegel's Philosophical and Aesthetic Development” (Hegelův filozofický a estetický vývoj, 2004a), Patočka argues, however, that architecture creates not only the most characteristic objects, landmarks, and points of reference of our surroundings, but also the "key feature of the space-form" (tvarově prostorové předznamenáni) of concrete life. Only in this key feature of space-form do the individual components of our surroundings gain their proper sense. This key feature shapes the landscape and the relations between the earth, the waters, and the heavens; it defines distance, security, peace, and danger (Patočka, 2004a, p. 301). The author also mentioned that Patočka views the structure of space as being built dramatically and historically, that is to say, it is different in different historical eras. He also points out that the structure of space is not a simple fact but is something that arrives (Patočka, 2004c, p. 450). Architectural artworks of different eras thus show the structure of space in a different manner. Or, the architectural artworks of different eras create different worlds, different ways of understanding reality. One must therefore consider Patočka's concept of the history of culture to be able to grasp the continuity and change in the nature of the heritage of sacred architecture that is present in modern secular architecture.

\section{Two Different Eras of Culture and of Architecture in Particular}

In the essay "Art and Time" (Umění a čas, 2004b), Patočka recognized two different eras in the cultural history of humankind (Patočka, 2004b, pp. 306-307). The first is called the "era of artistic culture". At that time, art was the predominant way of approaching the world. Man understood the truth of the world primarily through works of art. The divine was revealed through art, and the human gaze penetrated art directly to the truth which governed the world. The work of art was not recognized as such, that is, as an independent reality; the viewer's gaze passed through the artwork as if through a window to the reality that was to be grasped. Art presented a method of "living out, feeling and thinking", certain "religious or ritual questions", access to a "festive, extraordinary, deciding and divine" aspect of the world. This era lasted from the prehistory through the 19th century. Patočka believes that the second era began in the 19th century, and continues to the present day. This is called either the "era of aesthetic culture" or the "reflected era". Abstract terms were the predominant tool of approaching the world. All objects are scientifically analyzed, including works of art. This is characterized by the constitution of two new scholarly disciplines, aesthetics and art history. Scholars in these new disciplines have carried out extensive research and 
made important discoveries. Artistic production has been revealed to be a special kind of activity distinguishable from purely technical activity. Specific problems concerning works of art have been solved by determining abstract relations and laws. The work of art has been recognized as an independent reality. The viewer's gaze rests on the artwork itself. The artwork does not refer to something outside itself.

Patočka believes that the artworks of both the "artistic era" and the "aesthetic era" always open up a certain "world", in other words, a certain horizon of human existence. He considers this opening up of the world to be the opening up of being (Patočka, 2004b, p. 316). This world, in Heidegger' view, enables the fundamental orientation of human existence, and shows what a human being is, what a thing is, and what an animal is (Heidegger, 1978a, p. 169). Patočka (2004b, pp. 315-316) argued that the opening up of the complete world remains a fundamental operation performed by the work of art. He insists on this opening up of the world by the artwork, on this opening up of the horizon, even though, as he admits, the status of this world has radically changed during the previous centuries. Art is no longer able to open up the objective and binding world, but it does offer a subjective one. Patočka believes that the art of the present expresses the world rather than depict it. He also emphasizes that this expression provides conclusive evidence of human freedom.

We need such evidence today, in times that are scientific and technical. Patočka successfully demonstrates that modern science regards nature as absolutely inorganic, that is, as a system of abstract scientific formulas (Patočka, 1996, p. 116). Nature is conceived of as a totally predictable and exploitable system. It is a system of usable potentialities, an immense source of energy. This modern scientific view of nature also concerns humans. In the world today, the scientific and technical view of nature determines human life in all spheres - the social, the economic, the political, the environmental, and even in the private. Human beings are considered "items" in the accumulation and transformation of usable natural forces; they are "accumulated, calculated, utilized, and manipulated". At present, human beings are also considered items in the production and consumption process. Patočka argues that from the general scientific and technical view of nature the development of industrial production and consumption creates a self-governing system, a system of "unleashed production". Industrial production absorbs distribution, and is capable of planning future consumption. This production surpasses natural demand, creates unnatural demand, and forces consumers to expend all their energies to obtain the products on offer. This situation inevitably results in the "concealed imprisonment" of humankind, the imprisonment of the consumer. In this respect, Patočka focuses on the graduation of power "in the third person". It is this power which makes use of human beings as tools in its own development, in its own strengthening (Patočka, 2004b, pp. 310-321). In today's world, a work of art is evidence that a human being is no mere "accumulator or transformer" of natural forces. A work of art proves, on the contrary, that a human being is "a real creative source, freedom". Art represents a "massive protest" against the subordination of human beings to the process of unleashed production, to the process of increasing of power (Patočka, 2004b, p. 316).

The author would emphasize that the character of the heritage of sacred architecture in secular architecture can be well understood in the light of Patočka's reflections on the two eras in the cultural history of humankind. Both architectures - the sacred and the secular - open up a world, a horizon of human existence, even though the horizon of sacred architecture is binding and objective and the horizon of secular architecture is subjective. Modern secular architecture is therefore evidence of human freedom, of the human ability to remain part of the real creative process. In "Art and Time”, Patočka also points out that modern art can perform its role only if it is 
"part of reality", only if closely related to everyday life (Patočka, 2004b, pp. 314-316). Modern theatre surmounts the contradiction between the performance and the audience, modern sculpture abandons the pedestal, and modern painting is unconcerned with the visibility of the image surface. Modern art is thus not an "artificial paradise", not escapism. The function of modern art is not an escape from the problems of "everyday reality", but an expression of human freedom. The importance of modern secular architecture is evident from this perspective. Perhaps no other art can better serve as an expression of human freedom, because no other art is so close to the problems of common reality and everyday life.

\section{Conclusions}

In this paper, the author has traced out Patočka's theory of architecture. The author has sought to show that it is based on his conception of space, because material architecture is only a consequence of the primordial architecture of the construction of sensory fields, that is, a consequence of primordial architecture. The author has also traced out the problems in the relationship between the two modes of material architecture, the sacred and the secular. The author has sought to show that both these architectures open up a certain world, even though the character of the world opened up by sacred architecture is radically different from the world opened up by secular architecture. In Patočka's view, the worlds opened by works of architecture present the result of the revelation of being. Even though Patočka's theory of architecture is clearly inspired by Heidegger's reflections, the opinions of these two authors differ in this respect. Heidegger argues that the genuine edifice is inevitably related to the fourfold, that is, the unity of the earth, the sky, mortals, and divinities, but Patočka supposes that sacred architecture is enabled only by sacred transubstantiation. He argues that whereas sacred architecture depicts the omnipotence of divinity, secular architecture expresses the freedom of subjectivity. The author has sought to demonstrate that Patočka strongly emphasizes the importance of this expression today. It is in this context that the author sees the importance of modern secular architecture.

\section{References}

Heidegger, M. (1971). Building dwelling thinking. In A. Hofstadter (Ed.), Poetry, language, thought (pp. 145-161). New York: Harper \& Row.

Heidegger, M. (1973). Art and space. Man and World, 6(1), 3-8.

Heidegger, M. (1978a). The origin of the work of art. In D. F. Krell (Ed.), Basic writings (pp. 149-187). London and Henley: Routledge \& Kegan Paul.

Heidegger, M. (1978b). What is metaphysics?. In D. F. Krell (Ed.), Basic writings (pp. 95-112). London and Henley: Routledge \& Kegan Paul.

Patočka, J. (1991). Space and its problems (Prostor a jeho problematika). Estetika, 28(1), 1-37.

Patočka, J. (1992). Natural world as a philosophical problem (Přirozený svět jako filozofický problém). Prague: Československý spisovatel.

Patočka, J. (1996). Heretical essays in the philosophy of history. Chicago and La Salle: Open Court.

Patočka, J. (2004a). Hegel's philosophical and aesthetic development (Hegelův filozofický a estetický vývoj). In D. Vojtěch \& I. Chvatík (Eds.), Art and time I (Uměni a čas I) (pp. 227-302). Prague: OIKOYMENH.

Patočka, J. (2004b). Art and time (Umění a čas). In D. Vojtěch \& I. Chvatík (Eds.), Art and time I (Umění a čas I) (pp. 303-318). Prague: OIKOYMENH.

Patočka, J. (2004c). Thoughts on read's book about sculpture (Úvahy nad Readovou knihou o sochařství). In D. Vojtěch \& I. Chvatík (Eds.), Art and time I (Umění a čas I) (pp. 441-453). Prague: OIKOYMENH.

Read, H. (1961). The art of sculpture. New York: Bollingen Foundation. 